\title{
Interfaces entre teologia pública e bioética ${ }^{1}$
}

\section{Interfaces between public theology and bioethics}

\author{
Evandro Arlindo de Melo \\ Mário Antônio Sanches
}

\section{Resumo}

A Bioética é uma reflexão relativamente nova, que devido a seu caráter interdisciplinar se efetiva na interface com as demais áreas do conhecimento. Em sua relação com a Teologia surgem diversas indagações, sendo a principal: são pertinentes as interfaces entre estas duas áreas? Este artigo trabalha as relações e interfaces entre Teologia Pública e a Bioética, resgatando o pensamento de David Tracy que projeta uma reflexão teológica que sempre se dirige a três públicos, a saber, Igreja, Academia e Sociedade, sendo que para cada um destes há uma disciplina teológica específica, respectivamente, Teologia Sistemática, Fundamental e Prática. Isto possibilita uma renovação da reflexão e do discurso teológico, que amplia sua natureza privada e realizado para uma comunidade confessional, passando a efetivar-se para uma sociedade mais plural. Neste sentido, a Teologia Pública também auxilia a Bioética construída a partir de uma perspectiva teológica, possibilitando a essa desenvolver um discurso muito mais razoável para uma sociedade laicizada. Conclui-se que a reflexão bioética que ocorre no âmbito teológico estabelece intrinsicamente, ciente ou não, um diálogo com algumas características da Teologia Pública, tais como: abertura às ciências, diálogo com a sociedade, construção de argumentos com razoabilidade, consciência de que se atua em um cenário público e respeito à diversidade.

\footnotetext{
${ }^{1}$ O presente trabalho foi realizado com apoio da Coordenação de Aperfeiçoamento de Pessoal de Nível Superior - Brasil (CAPES) - Código de Financiamento 001.
} 
Palavras-chaves: Teologia Pública. Bioética. Razoabilidade. Diálogo com as ciências.

\begin{abstract}
Bioethics is a relatively new reflection, which due to its interdisciplinary character is effective at the interface with other areas of knowledge. In its relationship with theology, several questions arise, the main one being: are the interfaces between these two areas relevant? This article works on the relations and interfaces between Public Theology and Bioethics, rescuing the thought of David Tracy who projects a theological reflection that always addresses three audiences, namely, Church, Academy and Society, and for each of these there is a specific theological discipline, respectively, Systematic, Fundamental and Practical Theology. This makes possible a renewal of reflection and theological discourse, which expands its private nature and is carried out for a confessional community, becoming effective for a more plural society. In this sense, Public Theology also helps Bioethics built from a theological perspective, enabling it to develop a much more reasonable discourse for a laicized society. It is concluded that the bioethical reflection that occurs in the theological scope establishes intrinsically, aware or not, a dialogue with some characteristics of Public Theology, such as: openness to the sciences, dialogue with society, construction of arguments with reasonability, awareness that operates in a public setting and respects diversity.
\end{abstract}

Keywords: Public Theology. Bioethics. Reasonability. Dialogue with sciences.

\title{
Introdução
}

A Bioética é uma reflexão relativamente nova, surgiu na década de 70 do século passado. Embora o termo Bioética tenha sido usado pela primeira vez pelo teólogo protestante alemão Fritz Jähr no ano de 1927, em um artigo denominado "Bio-Ética: uma revisão do relacionamento ético dos humanos em relação aos animais e plantas", ${ }^{2}$ esta área ganhou mesmo sua existência

${ }^{2}$ JÄHR, F., Bio-Ethic. 
com o oncologista americano Van Rensselaer Potter, que publicou um artigo, no ano de 1970, com o título de "Bioética, a Ciência da Sobrevivência", ratificada um ano depois, em 1971, com o seu livro, já traduzido para o português, intitulado "Bioética: Ponte para o Futuro". ${ }^{4}$ Não obstante ao fato de Potter pretender uma Bioética de caráter mais global, o seu quadro reflexivo tornou-se mais limitado a questões ligada às ciências da saúde, quando esta passou a ser concretizada pelo obstreta católico holandês André Hellergers, que trabalhava na Universidade de Georgetown, na cidade de Washington, onde ajudou a fundar o Joseph and Rose Kennedy Institute of Ethics.

Esta nova disciplina, como gostam de considerar alguns, ou ciência, como pretendida por outros, ${ }^{5}$ acaba sendo uma área do conhecimento que não pode ser desenvolvida sem referência às outras áreas. Embora a epistemologia da Biética a considere como um "Ética Aplicada", desde seu nascimento ela se efetiva com sua característica principal: o fato de ser desenvolvida desde uma perspectiva interdisciplinar. Esta característica pode sofrer graduação, deste modo uma determinada reflexão Bioética pode ser mais ou menos interdisciplinar. Assim ela está aberta a estabelecer diálogo com todas as outras áreas do conhecimento, sendo um deles o teológico, mas nem sempre isto ocorre efetivamente, pois pode ocorrer tendências dentro da Teologia que se fecham ao diálogo com a Bioética ou tentam estabelecer este diálogo de modo não profícuo.

Quando se começa a desenvolver uma reflexão que relacionone Bioética e Teologia, suscita-se um debate epistemológico que justifique e situe a Bioética com uma adjetivação teológica, chamando esta, ou não, de Bioética Teológica. Esta discussão é suscitada porque alguns bioeticista acreditam não poder haver uma Bioética construída desde dentro de uma Tradição Religiosa, ou seja, desde um ambiente confessional, pois sendo este um ambiente destinado a consciência particular de cada indivíduo, ela perderia sua capacidade de ser realmente interdisciplinar e, assim, não teria nada a acrescentar no debate social bioético.

Para esclarecer esta posição basta trazer a reflexão do grande bioeticista

\footnotetext{
${ }^{3}$ POTTER, V. R., Bioethics.

${ }^{4}$ POTTER, V. R., Bioética.

${ }^{5}$ Aqui não interessa entrar em questionamento se a Bioética é, como queria V. R. Potter, uma ciência da sobrevivência, ou como definia D. Callahan, uma disciplina nova. Sobre esta discussão, tem um interessante artigo publicado no ano de 2003, trazendo justamente por título: "Bioética: Ciência ou disciplina" (SALAZAR, E., ¿Bioética).
} 
espanhol Diego Grácia, que tem uma das mais conceituadas obras que se destina a refletir sobre os Fundamentos da Bioética. ${ }^{6} \mathrm{O}$ autor defende a ideia de que a Bioética deve sempre ser concretizada na sua perspectiva secular, ou seja, a Bioética deve ter algumas características que são compiladas por José Ramón Amor Pan: racional, civil, autônoma, plural e interdisciplinar. ${ }^{7}$ Contrapondo-se a isto, defende-se neste trabalho, a tese de que existe sim a possibilidade de se falar em Bioética construída e relacionada em perspectiva teológica, desde que esta se apresente de modo a respeitar caraterísticas próprias da reflexão bioética desenvolvida em uma sociedade plural e secular. ${ }^{8}$

Para tanto, para se efetivar uma Bioética construída e refletida por teólogos, é preciso indagar, se todas as tendências e perspectivas da Teologia dialogariam bem com a Bioética ou, de uma outra forma, se há alguma abordagem ou ênfase teológica que possibilitaria um diálogo mais rico entre estas áreas? É a partir destas questões que este artigo busca propor, caracterizar e desenvolver a Teologia Pública como uma abordagem que brota da tradição teológica e ecoa significativamente nos ambientes seculares e interdisciplinares, apresentando interfaces significativas com a Bioética.

Quando se busca elaborar uma reflexão sobre a Teologia Pública se faz necessário perceber que há uma série de dificuldades que precisam ser consideradas, esclarecidas e superadas. Essas dificuldades já começam a surgir pelo próprio uso da terminologia "Teologia Pública", mesmo porque, esta estabelece uma gama de interpretações divergentes que podem significar, por um lado, a possibilidade de aplicar esse termo a diversas intenções de se construir uma Teologia com elementos mais políticos e sociais - como o foram respectivamente, por exemplo, a construção de uma Teologia surgida no contexto do regime do Apartheid na África do Sul e da Teologia da Libertação construída a partir do contexto de exploração econômica na América Latina. Por outro lado, este termo pode ser uma referência aplicada exclusivamente à questão discursiva da reflexão teológica que tenta ser efetivada numa realidade ad extra da Igreja e que, também, pode ser compreendida a partir de diferentes contextos e pontos de vistas, em

\footnotetext{
${ }^{6}$ GRACIA, D., Fundamentos de Bioética.

${ }^{7}$ AMOR PAN, J. R., Bernard Häring y la Bioética, p. 544-546.

${ }^{8}$ Essa temática tão importante, não poderá ser aprofundada neste trabalho, mas pode ser refletida com mais propriedade através do artigo publicado no ano de 2003, cujo título reflete justamente este questionamento se se pode existir uma Bioética com adjetivação teológica, ou como prefere o autor: "É possível falar de Bioética Teológica?" (VICO PEINADO, J., Cabe hablar de "Bioética Teológica"?).
} 
especial, postulando uma construção mais voltada à academia e à sociedade como um todo onde está inserida.

Deste modo, este artigo busca, primeiramente, apresentar brevemente a Teologia Pública, para depois situar a suas interfaces com a Bioética.

\section{Desenvolvimento da Teologia Pública}

A Teologia Pública nasce em território norte-americano na segunda metade do XX. Em relação ao seu surgimento é preciso ter em mente que ela, no primeiro momento, se estabelece em uma perspectiva protestante, em especial, a partir dos escritos de Martin Emil Marty e, em um segundo momento, em perspectiva católica, a partir da reflexão e dos escritos de David Tracy. Para se precisar essa dualidade de nascimento e desenvolvimento da Teologia Pública, convém apresentar separadamente cada uma destas perspectivas, enfatizando apenas os referenciais históricos fundamentais da questão aqui analisada.

\subsection{O nascimento da Teologia Pública na tradição protestante}

Teologia Pública surge em meados da década de 70 do século XX, coincidentemente, quase simultaneamente ao aparecimento da própria Bioética, estabelecendo-se com a proposição do teólogo luterano norteamericano Marty, quando o mesmo publica no ano de 1974, um artigo que tem por título "Reinhold Niebuhr: Teologia Pública e a experiência americana". Neste artigo, o autor reflete sobre o teólogo e pastor norte-americano Reinhold Niebuhr, que nasceu em 1892 e faleceu em 1971.

Niebuhr escreveu e publicou vários livros e artigos sobre Teologia e, mais especificamente, sobre moral, sendo considerado pelo próprio Marty como "o principal intérprete do século do comportamento social religioso americano". ${ }^{10}$ Sobre esse surgimento da Teologia Pública, esclarece o autor Alonso Gonçalves:

É comum entre os pesquisadores atribuir o termo ao teólogo estadunidense

Martin E. Marty (teólogo luterano) quando este escreve a um jornal de

\footnotetext{
${ }^{9}$ MARTY, M. E., Reinhold Niebuhr.

${ }^{10}$ MARTY, M. E., Reinhold Niebuhr, p. 334. Texto Original: “... the century's foremost interpreter of American religious social behavior".
} 
religião dos EUA, em 1974, sobre Reinhold Niebuhr, abordando o pensamento desse autor e a experiência religiosa na América do norte. ${ }^{11}$

Seguindo a isto, segundo Júlio Paulo Tavares Zabatiero, Marty começa a ter em mente que: "há um tipo de religião civil que desempenha uma função profética, crítica em relação à cultura, política e sociedade - e essa é a teologia pública". ${ }^{12}$ Para se fazer justiça neste sentido, é preciso enfatizar que embora no nascimento da Teologia Pública se tenha a consideração do que se entende por uma Religião Civil, não se pode confundir uma à outra. Cada uma, dentro de seu contexto, traz referências divergentes e têm objetivos diferentes, o que faz com que as postulações de Marty sejam apenas o início de uma discussão que será desenvolvida posteriormente em outros contextos.

Sobre essa diferenciação de Teologia Pública e Religião Civil, é possível referenciar Rudolf von Sinner, quando o mesmo esclarece que: "A diferença parece ser que a religião pública e a teologia pública são mais específicas, de certa forma confessionais (não separadas de religiões reais) e pluralistas (não unificadas) do que a religião civil". ${ }^{13}$

$\mathrm{O}$ autor, com isso, não só explicita a diferenciação sobre a Teologia Pública, conceito elaborado por Marty que pode, como visto anteriormente, ter a possibilidade de compactuar o mesmo com o que seria uma religião pública, com o conceito trazido à tona pelo legado de Niebuhr de Religião Civil, como desenvolve essa separação, indo além da mesma, afirmando que:

Uma teologia pública não visa, de modo algum, estabelecer uma teocracia, conforme suspeitava em seu tempo Espinosa, nem promover uma "teologia política" no sentido de Carl Schmitt, ou seja, uma secularização de conceitos teológicos por dentro da política, conforme descreve Marilena Chauí. Pelo contrário, procura-se uma teologia separada do âmbito da política num estado secular de direito que reconhece plenamente a liberdade religiosa, na qual procura contribuir como parceira crítico-construtiva pelo bem comum. Longe de querer uma teologia exclusiva e unilateral, busca defender o seu caráter acadêmico, plural e interdisciplinar. ${ }^{14}$

Embora este objetivo da Teologia Pública esteja claro nos dias atuais, é

\footnotetext{
${ }^{11}$ GONÇALVES, A., Teologia Pública, p. 64.

${ }^{12}$ ZABATIERO, J. P. T., O público em “Teologia Pública”, p. 75.

${ }^{13}$ SINNER, R. V., Teologia Pública no Brasil, p. 267.

${ }^{14}$ SINNER, R. V., Teologia Pública no Brasil, p. 267.
} 
preciso levar em conta que isto só foi possível com o desenvolvimento posterior da mesma. No início, esta especificidade não era assim tão clara e visível, mesmo porque, neste processo, como lembra Gonzalo Villagrán Medina: "muitos teólogos tentaram formular um método teológico que moldasse essa contribuição da teologia para o bem comum das sociedades pluralistas a partir dos símbolos e narrativas da fé cristã". ${ }^{15}$

Não obstante a essa imensurável contribuição de Marty e outros autores, a postulação da Teologia Pública com objetivos próprios que hoje se estabelecem, só se tornou possível quando esta reflexão transbordou a realidade protestante, e começou a se desenvolver dentro do contexto do catolicismo. Assim sendo, como pontua o próprio Medina, o surgimento dessa forma de se fazer Teologia no contexto protestante, não estava tão distante da reflexão teológica que haveria de se desenvolver no período pós Concílio Vaticano II e que norteou toda a reflexão de tradição Católica. Sobre isto, assim reflete o referido autor:

Se olharmos para a confissão cristã à qual a maioria dos teólogos citados pertence, podemos ver que a teologia pública surge em contextos protestantes, um contexto teológico marcado pela idéia dos "cinco solas" ("sola Fide, sola Gratia, sola Scriptura, solus Christius, soli Deo gloria"). A principal preocupação desses primeiros teólogos é garantir que a formulação das consequências sociais do cristianismo não seja diluída na linguagem técnica da política ou da economia, mas que mantenha a inspiração original das Escrituras cristãs na mensagem. Essa preocupação não era estranha ao catolicismo pós-conciliar, que queria colocar em prática a afirmação do Vaticano II de que "o estudo da Sagrada Escritura deve ser como a alma da Teologia Sagrada". ${ }^{16}$

\footnotetext{
${ }^{15}$ MEDINA, G. V., Teologia Pública, p. 640. Texto Original: “... han sido muchos los teólogos que han intentado formular un método teológico que dé forma a esta contribuición de la Teología al bien comum de las sociedades pluralistas desde los símbolos y narrativas propias de la fe Cristiana".

${ }^{16}$ MEDINA, G. V., Teologia Pública, p. 640. Texto original: "Si nos fijamos en la confesión Cristiana a la que pertenecen la mayoría de los teólogos citados podemos ver que la teología pública surge en entornos protestantes, un contexto teológico marcado por la idea de las 'cinco solas' ('sola fide, sola gratia, sola Scriptura, solus Christius, soli Deo gloria'). La preocupación de fundo de estos primeros teólogos es asegurar que la formulación de las consecuencias sociales del cristianismo no se diluya en el lenguaje técnico de la política o la economía, sino que mantenga la inspiración originaria de la Escritura cristiana en el mensaje. Esta preocupación no era ajena al catolicismo post-conciliar que quería llevar a la práctica la afirmación del Vaticano II de que 'el estudio de la Sagrada Escritura ha de ser como el alma de la Sagrada Teología".
} 
Por isso, convém agora estabelecer uma análise no desenvolvimento da Teologia Pública dentro de outro contexto, a saber, o do catolicismo norteamericano.

\subsection{O desenvolvimento da Teologia Pública na tradição Católica}

Se a Teologia Pública norte-americana nasceu no seio do protestantismo, tão arraigado neste país, é preciso afirmar que foi no contexto do catolicismo que ela se desenvolveu e ganhou o contorno que hoje prevalece, em especial, pelo pensamento e obras do já referenciado Tracy.

Esta posição torna-se clara com a postulação de Zabatiero, que afirma categoricamente que foi no meio católico que o sentido da Teologia Pública chegou mais próximo ao que hoje se pode estabelecer para tal, pois como o mesmo sintetiza: "Foi no âmbito do catolicismo norte-americano que a expressão teologia pública passou a se aproximar do sentido mais geral que possui hoje em dia, graças especialmente ao trabalho de David Tracy". ${ }^{17}$

Diante disso, não se pode deixar de destacar o trabalho deste grande autor do ano de 1981, intitulado de: "A imaginação analógica: A teologia cristã e a cultura do pluralismo". ${ }^{18}$ Esta obra, que por sua importância, já foi traduzida em várias línguas, inclusive para o português, se tornou referencial no estudo e desenvolvimento da Teologia Pública, não só no contexto norte-americano, mas mundial. Tracy realiza neste escrito uma grande análise de como a reflexão teológica deve se desenvolver e como nunca deixa de ter uma perspectiva pública, mesmo quando realizada dentro de uma comunidade confessional e quando tem como interlocutores fiéis de uma determinada tradição religiosa.

Das muitas contribuições de Tracy para a questão aqui refletida, quiçá a mais contundente expressa no seu livro com muita competência e profundidade no contexto da efetivação da Teologia Pública, é a ideia de que quando se realiza uma reflexão teológica, ela deve ter em mente que o resultado é sempre um discurso que diga respeito a três realidades distintas, a saber: a sociedade, a academia (universidade) e a Igreja.

Tracy começa a expressar essa distinção de públicos em seu pensamento, quando afirma, em primeiro lugar, que: "Se alguém está preocupado em

\footnotetext{
${ }^{17}$ ZABATIERO, J. P. T., O público em “Teologia Pública”, p. 75.

${ }^{18}$ TRACY, D., The analogical imagination.
} 
mostrar o caráter público de toda a teologia, torna-se imperativo estudar primeiro os grupos de referência, os 'públicos', do teólogo". ${ }^{19}$ Para o autor, é fundamental ter em mente o público que se está dirigindo a reflexão teológica, sem deixar de lado os demais interlocutores que também são destinatários secundários desta mesma reflexão.

Para deixar claro o que quer dizer com isto, o próprio Tracy enfatiza que ao construir uma reflexão teológica e, consequentemente, um discurso a partir da Teologia:

Todo teólogo se dirige a três realidades sociais distintas e relacionadas: a sociedade mais ampla, a academia e a igreja. Um desses públicos será o destinatário principal, ainda que raramente exclusivo. A realidade de um lócus social particular certamente afetará a escolha da ênfase. ${ }^{20}$

Sobre estas três realidades, intentando aprofundá-las no que diz respeito a serem elas o objetivo do discurso construído a partir de uma reflexão teológica e, em especial, a partir da Teologia Pública, esclarece Gonçalves, especificando que a cada um destes destinatários, se devem enfatizar aspectos imprescindíveis:

Na sociedade, onde se concentram diferentes vozes que contribuem para o ethos de sociedade, sendo esse ethos hoje dominado pela globalização e a tecnologia, esta última tendo a proeminência, a Teologia Pública seria mais uma voz, principalmente no âmbito político. Quanto a academia, a Teologia Pública teria o seu espaço, a exemplo de países europeus onde a teologia tem a sua especificidade no processo de maturação do ser humano, ela deixaria de ser estritamente confessional e faria um processo de inserção na sociedade secularizada. A proposta é fazer com que a universidade seja influenciada por uma leitura teológica da realidade. A tentativa é dotar a teologia do mesmo status sociopolítico de outras disciplinas. Na Igreja como um segmento social, um grupo de pessoas que tem na fé a razão de ser, a Teologia Pública teria a função de fornecer meios para que a comunidade tivesse uma maior participação na sociedade, renovando, instruindo e ampliando horizontes para além da confessionalidade e dos problemas corriqueiros de uma comunidade religiosa. ${ }^{21}$

\footnotetext{
${ }^{19}$ TRACY, D., A imaginação analógica, p. 20.

${ }^{20}$ TRACY, D., A imaginação analógica, p. 23.

${ }^{21}$ GONÇALVES, A., Teologia Pública, p. 68.
} 
Tendo em mente tudo isso, se pode dizer que pensar a Teologia como um discurso que possa levar em conta realidades tão distintas é uma situação complexa, o que evoca repensar, como fez Tracy, a própria forma como se constrói a reflexão teológica. Por isso, o autor, ao postular o desenvolvimento da chamada Teologia Pública, sugere que: "a teologia com enfoque primário num ou outro público pode ser dividida em três subdisciplinas distintas". ${ }^{22}$

Esta sua proposição se esclarece ao pensar a complexidade da realização da reflexão teológica diante dos três públicos, sendo que, o mesmo Tracy pontua esta situação, afirmando que: "minha hipótese é que a melhor maneira de esclarecer essa complexidade é propondo a existência de três disciplinas distintas, mas relacionadas na teologia: teologia fundamental, sistemática e prática. Cada disciplina é distinta, ainda que internamente relacionada com as outras duas". ${ }^{23}$

Ao pensar essas três disciplinas para a Teologia, Tracy tem consciência de que não está dividindo o conteúdo central da própria reflexão teológica, pois, como ele mesmo afirma: "a teologia como tal permanece uma única disciplina que demanda publicidade". ${ }^{24} \mathrm{O}$ que o autor está intentando é que ao procurar realizar um discurso público para a Teologia, levando em conta os três públicos distintos ao qual esta se objetiva, deve-se pensar maneiras diferentes de se realizar estes mesmos discursos.

Em sendo assim, convém explicitar a definição de cada um dos grupos destas disciplinas para Tracy, o que deixará ainda mais clara a sua intenção de ver a Teologia a partir destas mesmas três disciplinas ou, como ele mesmo prefere afirmar, dessas aplicações da reflexão teológica.

Para começar, é importante fixar-se na disciplina teológica chamada de fundamental que, segundo o autor, pode ser considerada como teologias ditas fundamentais. Neste primeiro grupo de reflexão, estas teologias deverão estar preocupadas, prioritariamente:

Em mostrar a adequação das alegações de verdade, usualmente aos postulados cognitivos, de uma tradição religiosa particular. Elas farão isso comumente empregando algum paradigma explícito do que constitui a argumentação objetiva em alguma disciplina reconhecida pela comunidade acadêmica mais ampla. ${ }^{25}$

\footnotetext{
${ }^{22}$ TRACY, D., A imaginação analógica, p. 87.

${ }^{23}$ TRACY, D., A imaginação analógica, p. 86-87.

${ }^{24}$ TRACY, D., A imaginação analógica, p. 87.

${ }^{25}$ TRACY, D., A imaginação analógica, p. 92.
} 
Segundo esta proposição do autor, pode-se dizer que a disciplina da Teologia Fundamental, ou como ele mesmo prefere chamar, as Teologias Fundamentais, tem seu público referencial o da "Academia", podendo ser a Filosofia esta disciplina reconhecida pela comunidade acadêmica mais ampla, uma vez que a mesma poderá estabelecer condições de racionalidade no discurso por elas construídas.

Por outro lado, Tracy enfatiza que a disciplina sistemática, ou como ele mesmo se refere no plural, Teologias Sistemáticas: "assumirão ordinariamente (ou assumirão argumentos prévios em favor de) o caráter portador de verdade de uma tradição religiosa particular". ${ }^{26}$ Isso acaba determinando que esta base disciplinar se dirige, preferencialmente, para o público "Igreja", sendo que seguindo o pensamento do autor, estas mesmas Teologias Sistemáticas: "enfocarão, desse modo, as reinterpretações e novas aplicações daquela tradição para o presente". ${ }^{27}$

Por fim, o autor determina como terceira disciplina a Teologia Prática, ou como ele mesmo prefere referenciá-la, como as Teologias Práticas. Tracy considera que no caso deste último grupo de desenvolvimento da reflexão teológica, estas Teologias Práticas deverão analisar:

\begin{abstract}
Alguma situação radical de importância ético-religiosa (sexismo, racismo, classismo, elitismo, antissemitismo, exploração econômica, crise ambiental, etc.), de alguma maneira filosófica, sociocientífica, culturalmente analítica ou religiosamente profética. Elas assumirão ou argumentarão que essa situação é a situação mais importante (ou ao menos uma das) que demanda o envolvimento, o compromisso e a transformação teológicos. ${ }^{28}$
\end{abstract}

Assim fica claro, que a base disciplinar prática está diretamente relacionada ao público "Sociedade", com uma perspectiva muito mais estruturada a partir da ação em problemas sociais, o que evocou, seguindo a este pensamento, ao estabelecer uma Teologia Pública radicada nas realidades mais políticas e sociais, tornando-se eminentemente visível, como já referenciado, na Teologia do Apartheid, no continente africano, ou na Teologia da Libertação, na América Latina.

\footnotetext{
${ }^{26}$ TRACY, D., A imaginação analógica, p. 92.

${ }^{27}$ TRACY, D., A imaginação analógica, p. 92.

${ }^{28}$ TRACY, D., A imaginação analógica, p. 92-93.
} 
Toda essa descrição do pensamento de Tracy ajuda a perceber a contribuição que a própria Teologia Pública poderá trazer na tentativa de desenvolvimento tanto para a Teologia em geral, quanto da própria Bioética, como se analisará a seguir.

\title{
2. A Bioética pensada na interface com a Teologia Pública
}

Como o que se pretende com este artigo é situar as interfaces entre Teologia Pública e Bioética, torna-se importante retomar o pensamento de José Roque Junges, citado por Gonçalves. Para ele, a Teologia Pública, de maneira especial aquela que se constrói a partir da universidade, deve se estabelecer como presença de uma reflexão desenvolvida pela fé cristã dentro das questões próprias e hodiernas da Bioética, sendo que isto acontece em dois sentidos:

\begin{abstract}
Por um lado, uma teologia que se deixe questionar pelos desafios da ciência, pois a universidade é o lugar por excelência para deixar-se questionar por esses desafios, como por exemplo, os lançados pela biologia, pela genética etc. Para discutir estas questões, ela necessita de liberdade acadêmica. Não se pode repetir o que sempre foi dito, mas tentar novas compreensões e interpretações. É claro que ela precisa seguir o estatuto epistemológico próprio da teologia, tendo como ponto de partida a revelação e a tradição, mas com uma abertura para repensar esses dados nos desafios atuais. Um segundo sentido dessa presença da Teologia Pública é que ela seja uma presença crítica. Uma visão humanista que enfrente criticamente os processos do paradigma da Modernidade presente na ciência e na sociedade. Portanto, a Teologia Pública, por um lado, deixa-se desafiar pelas ciências atuais e, por outro, também desafia criticamente as ciências em seus pressupostos. ${ }^{29}$
\end{abstract}

Este elemento - abrir-se para os desafios das ciências - coloca a Teologia Pública no mesmo cenário da Bioética. Para situar melhor as interconexões entre estas duas áreas vê-se por bem organizar esta reflexão analisando a importância da Teologia Pública para a reflexão teológica em geral, objetivando ir além da forma como a reflexão tradicional da teologia é efetivada e, por isso mesmo, faz emergir, de suas próprias características, a sua relevância para a Bioética.

${ }^{29}$ GONÇALVES, A., Teologia Pública, p. 72. 


\title{
2.1. A renovação da reflexão teológica na Teologia Pública
}

O contributo da Teologia Pública, como renovação do fazer teológico que se aplica ao debate social, se faz necessário atualmente não só no âmbito da relação da Teologia com a própria Bioética, mas também, da Teologia com as outras áreas de saber. Isto se torna indispensável pela consequência da mudança de compreensão da forma como a Religião deve se relacionar com outros saberes, no contexto de um processo de globalização enfatizado nas últimas décadas. Sobre o problema trazido por este processo de globalização para a Religião e a Teologia, Rodrigo Muñoz afirma que:

\begin{abstract}
A globalização impõe a tarefa de renovar a compreensão moderna da relação religião-política, tanto em sua expressão teórica - o paradigma da secularização - quanto em sua reflexão prática - o modelo de secularismo. Em que sentido a renovação pode ser pensada? O que foi dito até agora é verdadeiro, no sentido das tendências que caracterizam a sociedade moderna neste ponto: primeiro, é "secular" no sentido de se diferenciar em diversas esferas com autonomia própria; segundo, a religião está presente nela de maneiras relevantes, que variam com as circunstâncias históricas e culturais de cada área. ${ }^{30}$
\end{abstract}

Com esta assertiva, falando especificamente da secularização e da laicização da sociedade moderna que se intensificou pelo processo de globalização, o referido autor quer propor a noção de um Estado neutro no que diz respeito à questão da Religião, que teria neste específico, uma função de moderação, tornando-se assim totalmente imparcial para dirimir possíveis contradições que possam vir a surgir neste mesmo processo. Embora esta neutralidade esteja, ou pelo menos deveria estar, presente em todos os Estados Democráticos de Direito, não se quer dizer que os cidadãos são também obrigados a serem neutros, especificamente quando se refere à confessionalidade que cada um venha a professar.

\footnotetext{
${ }^{30}$ MUÑOZ, R., La religión em la esfera pública, p. 652. Texto original: "La globalización impone la tarea de renovar la comprensión moderna de la relación religión-política, tanto en su expresión teórica - el paradigma de la secularización -, como en su reflejo práctico - el modelo de laicidad -. ¿En qué sentido cabe pensar la renovación? Se lo dicho hasta aquí es cierto, en el sentido de las tendencias que caracterizan en este punto la sociedad moderna: primero, es 'secular' en el sentido de diferenciada en ámbitos diversos con autonomía propia; segundo, la religión está presente en ella de formas relevantes, que varían con las circunstancias históricas y culturales propias de cada área".
} 
Em sendo assim, não se pode olvidar que compete à Teologia, convidada a renovar-se pela reflexão trazida pelo Concílio Vaticano II, dar uma resposta mais plausível das proposições cristãs, deixando para trás uma reflexão teológica voltada apenas para dentro da Igreja.

Aqui talvez convenha lembrar que esta participação da reflexão teológica no debate social, indo além de uma forma tradicional de se efetivar a mesma, não é apenas uma imposição da Teologia feita a si própria, mas que acaba sendo uma participação solicitada por parte da sociedade. Esta mesma sociedade encontra-se inquieta com diversas questões que lhe são apresentadas e que está aberta a colaborações que lhe sejam plausíveis de todas as áreas de conhecimento humano.

Para entrar neste debate, da parte da Teologia, deve haver uma reestruturação que começa na renovação dos próprios conteúdos, indo para além da maneira tradicional de se estruturar. Seguindo a isto, é preciso deixar de se construir uma Teologia privada e dar a esta um caráter eminentemente público, fazendo-a partícipe do mundo onde está inserida. Para que isso aconteça, é preciso, como afirma Cesar Kuzma: "fazer uma teologia que não se ocupe apenas de coisas religiosas, mas, também, daquelas coisas que sempre foram julgadas como profanas e estranhas à fé. (...) não mais uma teologia privada, mas uma teologia pública, que se sinta responsável pelo mundo em que está inserida". ${ }^{31}$

Quando se busca uma Teologia que vá além da sua forma tradicional de ser, isto não quer dizer que a mesma deva se curvar diante dos outros saberes. A Teologia, mesmo quando em sua construção pública se volta a uma sociedade de característica laical, não pode perder sua identidade própria, preservando aquilo que tem de específico e que seja imprescindível enquanto contribuição para esta mesma sociedade, por isso aqui, a proposição da Teologia Pública.

Referindo-se a esta reflexão, Sanches afirma que o contato da Teologia com os outros saberes, em especial, com as ciências da saúde, se faz necessário a partir de uma atitude de diálogo. Se preciso for, esta mesma reflexão deve-se inclusive modificar-se em alguns momentos, para que esteja compatibilizada com os problemas atuais. No entanto, isto não pode significar submissão. Neste sentido, o autor ressalta que:

Mudar a teologia não pode significar a sua submissão à ciência. Entendemos aqui que "mudar" significa estar em condições de dialogar com essa

${ }^{31}$ KUZMA, C., A teologia no universo científico e a sua especificidade epistemológica, p. 238. 
realidade, se abrir para participar do desenvolvimento científico que está ocorrendo e poder fazer uma reflexão que nasça da tradição teológica e esteja sintonizada com os problemas levantados na atualidade. ${ }^{32}$

Boaventura Souza Santos parece aprofundar toda esta perspectiva, especialmente, quando se refere às contribuições que a Teologia pode efetivar em sua análise e detalhamento dos problemas sociais que são tão caros à Bioética, quando estes estejam relacionados à vida, baseando sua proposição na necessidade de se retomar a própria epistemologia da reflexão teológica. Não obstante o fato desta estar baseada em algo que esteja além de qualquer prova científica, acaba tendo uma importância miríade, tanto diante dos já citados problemas sociais, mas também, na relação que se pode estabelecer diante dos demais saberes. Sobre isto, assim afirma o autor:

O saber teológico tem a sua epistemologia própria e, com base nela, pode ser considerado incomensurável como o saber científico. Basta pensar que a Teologia cristã assenta na revelação, um facto insusceptível de prova científica. Se passarmos ao saber em geral que corresponde ao saber teológico, o saber religioso, a questão da relação entre saberes assume uma grande importância dado que, por exemplo, muitos movimentos sociais que lutam hoje contra a desigualdade, a exclusão e a opressão assentam a sua militância e a sua acção em saber religioso combinado com saber científico. ${ }^{33}$

É por tudo isso que se requer da reflexão teológica atual, em especial quando a mesma intenta relacionar-se com a Bioética, uma nova postura no debate social, que vá além de sua forma tradicional. Essa postura, que se acredita poder ser estabelecida pela própria contribuição da Teologia Pública, busca novas formas de se portar diante das novas tecnologias, das outras ciências e da própria reflexão acadêmica hodierna. Kuzma ${ }^{34}$ acrescenta que o discurso teológico envolvendo a Bioética só terá sentido no debate social, apresentando soluções aos problemas que são levantados atualmente, se a Teologia der respostas pautadas em outros horizontes além de sua formulação estritamente interna e voltada à confessionalidade. Especificamente o autor se refere que isto deve ser realizado, neste caso, baseando suas postulações nos demais saberes, conhecimentos e ciências.

${ }^{32}$ SANCHES, M. A., Brincando de Deus, p. 139.

${ }^{33}$ SANTOS, B. S., Por um novo senso comum, p. 150.

${ }^{34}$ KUZMA, C., A teologia no universo científico e a sua especificidade epistemológica 
Por sua vez, Muñoz considera que, dentre tantas tarefas, a reflexão teológica deve sempre fomentar dois pontos ou papéis específicos, a saber: "a) Promover relações de colaboração entre fé religiosa e razão, para que ambas sejam benéficas e sirvam ao progresso humano "; ${ }^{35} \mathrm{e}$ "b) A teologia e todas as formas de educação religiosa também desempenham um papel importante no relacionamento do cristianismo com as grandes tradições religiosas, fruto de maior conhecimento e respeito mútuo". ${ }^{36}$

Efetivando-se uma reflexão teológica neste sentido, chega-se à conclusão que: "uma teologia pública, assim, seria uma reflexão que ajudaria a cidadania a conhecer adequada e emancipatoriamente sua própria realidade e condição, a fim de poder agir e deliberar de modo crítico e construtivo". ${ }^{37}$ Em sendo assim, se pode afirmar que o objetivo da Teologia Pública tem por foco principal ajudar a estabelecer o bem comum da sociedade, não se comparando, por exemplo, às proposições da Teologia Política, ou mesmo da Teologia da Libertação latino-americana, pois estas estão mais direcionadas a uma mudança da práxis da própria confissão religiosa a que pertencem.

\subsection{A Bioética como espaço para a Teologia Pública}

Por tudo o que foi visto anteriormente, fica claro que na reflexão teológica atual, a Teologia Pública tem muito a oferecer por trazer uma nova forma de se fazer Teologia diante de um mundo secularizado, globalizado e laicizado, onde nenhum saber é absoluto e, além disto, por instigar os partícipes do debate social a apresentar proposições razoáveis para serem ouvidos por todos os envolvidos no diálogo. Diante disso, convêm perguntar: de que modo essa mesma forma de fazer Teologia se relaciona com a Bioética, em especial, aquela que busca se estruturar no âmbito da Teologia?

Inicialmente é importante considerar que a Bioética é um campo privilegiado para o diálogo entre a Teologia e o mundo moderno. É possível afirmar tal proposição, porque as postulações de assertivas bioéticas acabam levando a tomadas de decisões que envolvem todo o complexo de dimensões

\footnotetext{
${ }^{35}$ MUÑOZ, R., La religión em la esfera pública, p. 661. Texto original: “a) Promover relaciones de colaboración entre la fe religiosa y la razón, de forma que ambas resulten provechosas y sirvan al progreso humano".

${ }^{36}$ MUÑOZ, R., La religión em la esfera pública, p. 663. Texto original: “b) La teología y toda forma de educación religiosa tienen también un papel importante en la relación del cristianismo con las grandes tradiciones religiosas, fruto de un mayor conocimiento y respeto recíproco".

${ }^{37}$ ZABATIERO, J. P. T., O público em “Teologia Pública”, p. 83.
} 
da vida de um ser humano, inclusive o que se pode definir como uma dimensão pública ou política, ou seja, do relacionamento de cada indivíduo dentro da mesma sociedade. Seguindo a isto, não se pode prescindir, como afirma Ronald Thiemann, que: "Se a tomada de decisões morais tem uma dimensão política inevitável, a reflexão moral e teológica deve procurar ajudar os cristãos a lidar com os aspectos públicos de suas vidas", ${ }^{38}$ o que acaba sendo efetivado, sobretudo, no âmbito da Bioética.

Isto tudo é precisado, ainda, com a postulação de Volmir Fontana e Euler Renato Westphal, que sobre a questão aqui desenvolvida, afirmam que: “o diálogo com o mundo científico pode acontecer de forma produtiva por meio da bioética. (...) o diálogo é possível em uma sociedade em que a religião se apresenta de forma secularizada". ${ }^{39}$ Esta proposição também é considerada por diversos autores e serve de base para se relacionar a Teologia com a própria Bioética, uma vez que diante dos desafios trazidos pelo mundo científico, se faz necessário pensar num discurso teológico que enfrente estas questões utilizando aquilo que de específico se tem na reflexão bioética e que pode favorecer a presença da Teologia no debate social.

Assim, intenta-se afirmar neste ponto, que é possível construir um discurso público - partindo da perspectiva teológica-razoável para a Bioética, que seja significativo para uma sociedade secular e plural. Afirma-se, também, a possibilidade de se estabelecer uma estratégia de como este mesmo discurso poderá ser levado adiante.

Esta estratégia, ou se se quiser, esta metodologia, embora seja apenas um meio e não uma normativa rígida, torna-se imprescindível neste contexto, uma vez que o discurso realizado por uma Bioética de perspectiva teológica, só será eloquente e atingirá o seu objetivo no debate social, se for razoável, como já frisado, estabelecendo-se com proposições razoáveis.

Sobre o que significa ser razoável, convém lembrar uma assertiva do próprio Tracy, que ao refletir sobre esta questão, procura deixar claro que quando se afirma isto, deve-se ter em mente, antes de tudo, que:

Ser razoável não incluiu a necessidade de ser lógico. Ser lógico é não se contradizer. Argumentar é ser tão coerente quanto o tema assim o

${ }^{38}$ THIELMANN, R., Constructing a public Theology, p. 19. No original: "If moral decision making has an inevitable political dimensión, then moral and theological reflection must seek to assist Christians in dealing with the public aspects of their lifes".

${ }^{39}$ FONTANA, V.; WESTPHAL, E. R., Teologia Pública e Bioética, p. 72. 
permitir. (...) Depois podem aparecer questões mais sofisticadas e novas evidências relevantes. Neste caso, é racional mudar a decisão anterior. Por ora, no entanto, tem-se o direito racional de afirmar ter chegado a um juízo razoável, isto é, um juízo público (quer como conhecimento ou como crença religiosa). ${ }^{40}$

Esta postulação, antes de criar dificuldades de relacionamentos da reflexão teológica no contato com outros saberes dentro do debate social bioético, pontua algo que lhe é fundamental, a saber, a não absolutização das proposições, o que tornaria o diálogo, inclusive com a mesma Bioética, impossível de ser realizado na esfera pública. Assim sendo, essa postura, que é própria da Teologia Pública e que deve permear a construção de um discurso bioético a partir da própria confessionalidade, auxilia e faz crescer todo o debate social, pois como ainda afirma Tracy neste sentido:

\begin{abstract}
Talvez a religião - quando aparece na esfera pública - possa não apenas enriquecer a discussão pública sobre os fins (por exemplo, uma sociedade boa, promovendo o bem comum, a dignidade humana e os direitos de cada pessoa), mas também - e parece irônico dizê-lo ajudar a própria esfera pública para que ela mesma resista à contínua colonização tecnocêntrica. ${ }^{41}$
\end{abstract}

Esta contribuição, por assim dizer, é compartilhada por outros autores, como por exemplo, o já referenciado Medina, que ao falar da forma como Tracy estabelece o desenvolvimento desse diálogo no debate social, expressa que o mesmo o faz articulando a reflexão teológica com os conhecimentos trazidos pelas ciências sociais, objeto primeiro do desenvolvimento do pensamento bioético.

Assim, para Medina: "Tracy articulará os dois polos, as ciências teológicas e as sociais, principalmente da hermenêutica: as conclusões de ambos os polos devem ser interpretadas e dialogadas". ${ }^{42}$ Isto tudo acontece pois o autor referencial do desenvolvimento teórico da Teología Pública dentro da Tradição Católica: "entende essa colaboração como uma analogia, ou seja,

\footnotetext{
${ }^{40}$ TRACY, D., A Teologia na Esfera Pública, p. 30-31.

${ }^{41}$ TRACY, D., A Teologia na Esfera Pública, p. 36.

${ }^{42}$ MEDINA, G. V., Teologia Pública, p. 645. Texto original: “Tracy articulará los dos polos, el teológico y el de las ciencias sociales, principalmente a partir de la hermenéutica: las conclusiones de ambos polos ha de ser interpretados y puestas en diálogo".
} 
como uma descoberta, além das diferenças existentes, ordenou as relações da existência do homem e do mundo para o mesmo ponto focal: Deus". ${ }^{43}$

Quando esta realidade se dirige à praça pública, em especial, a partir da construção de um discurso bioético, talvez acabe por fazer surgir um problema que é preciso não só ser considerado, mas desenvolvido no sentido de se chegar a uma solução plausível, a saber:

O grande desafio para uma teologia que quer ir à praça pública é como mediar símbolos e narrativas religiosas com realidades sociais, respeitando a integridade de ambos os pólos. A mediação entre esses dois pólos não é fácil e é fácil cair em uma teologia indutiva que impõe conclusões das ciências sociais à revelação ou em uma teologia dedutiva que impõe uma certa visão teológica sobre a realidade. ${ }^{44}$

A solução deste grande desafio pode ser estabelecida quando se leva em conta dois aspectos fundamentais nesse processo de construir uma reflexão bioética a partir da confessionalidade e da religião para uma sociedade com características plural e secular.

O primeiro aspecto é muito bem esclarecido por Sinner:

A religião cristã é uma religião pública, no sentido de transmitir sua mensagem ao público mais amplo, interessar-se pelo bem-estar não apenas de seus membros, mas também daqueles que não fazem parte de uma igreja ou comunidade. (...) A primeira tese, portanto, é que o cristianismo é uma religião intrinsecamente pública. ${ }^{45}$

Nesta perspectiva o autor propõe que todos os cristãos devam dialogar sem medo com a sociedade como um todo, pois isto é próprio de sua identidade confessional. Neste aspecto convêm, ainda, mencionar novamente Medina, que para explicitar este pensamento, recorre ao fundador, por assim dizer,

${ }^{43}$ MEDINA, G. V., Teologia Pública, p. 643. Texto original: “... entiende esta colaboración como una analogía, es decir, como un descubrir, más allá de las diferencias existentes, relaciones ordenadas de la existencia del hombre y del mundo a un mismo punto focal: Dios".

${ }^{44}$ MEDINA, G. V., Teologia Pública, p. 644. Texto original: "El gran desafío para una teología que quiere dirigirse a la plaza pública es cómo mediar los símbolos y narrativas religiosas con las realidades sociales respetando la integridad de ambos polos. La mediación entre estos dos polos no es sencilla y es fácil caer en una teología inductiva que imponga conclusiones de las ciencias sociales a la revelación, o una teología deductiva que impongan una determinada visión teológica a la realidad".

${ }^{45}$ SINNER, R. V., Teologia Pública no Brasil, p. 25. 
da Teologia Pública, afirmando que o próprio projeto de Marty auxiliaria no convencimento dos cristãos-católicos, uma vez que:

O projeto de Marty de uma teologia pública que contribui para o bem de uma sociedade pluralista a partir de confissões religiosas particulares está muito próximo de declarações do Vaticano II, como o convite à Igreja para colaborar com a sociedade (Gaudium et Spes, 40), para o Cristãos como protagonistas ativos da vida social (Gaudium et Spes, 30), e o desejo da Igreja de se expressar usando os símbolos e estilos mais apropriados da tradição cristã (Optatam totius, 16). ${ }^{46}$

Por tudo isso, e estabelecendo o segundo aspecto desta reflexão, explicita-se claramente que a Teologia Pública tem muito a contribuir para a construção de um discurso razoável da Bioética para uma sociedade plural e secular, tornando esse mesmo discurso eloquente e significativo. Isto porque, não se pode olvidar que a participação da reflexão teológica neste sentido torna-se fundamental à medida que também ela acaba sendo expressão que revela ao público em geral, e não só a indivíduos que participem ativamente de uma ou outra tradição religiosa e/ou confessionalidade, sentidos e verdades que acabam por fazer parte de toda a realidade da dimensão da vida humana.

É isto, por exemplo, o que postula o próprio Tracy, que ao refletir sobre os elementos teológicos, e porque não estender isso à reflexão bioética, afirma expressamente que:

Em termos inicialmente gerais, um discurso público revela sentidos e verdades que, em princípio, são capazes de transformar todos os seres humanos de alguma maneira pessoal, social, política, ética, cultural ou religiosa reconhecível. Por essa razão, ficará demonstrado que as marcas registradas da publicidade são a abertura cognitiva e a transformação pessoal, comunal e histórica. (...) Por exemplo, o discurso teológico cristão serve a uma função autenticamente pública quando ele torna explícito o caráter público do sentido e da verdade de que estão imbuídos os textos, eventos, imagens, rituais, símbolos e seres humanos cristãos clássicos. ${ }^{47}$

\footnotetext{
${ }^{46}$ MEDINA, G. V., Teologia Pública, p. 641. Texto original: "El proyecto de Marty de una teología pública que contribuya al bien de una sociedad pluralista desde las confesiones religiosas particulares está muy cercano a afirmaciones del Vaticano II como la invitación a la Iglesia a colaborar con la sociedad (Gaudium et Spes, 40), a los cristianos a ser protagonistas activos de la vida social (Gaudium et Spes, 30), y el deseo de la Iglesia de expresarse utilizando los símbolos y estilos más proprios de la tradición cristiana (Optatam totius, 16)".

${ }^{47}$ TRACY, D., A imaginação analógica, p. 86.
} 


\section{Conclusão}

No tocante às relações entre Teologia e Bioética nota-se que esta última, por característica própria, está aberta à reflexão interdisciplinar, mas que nem toda reflexão teológica consegue marcar alí uma presença significativa. Neste artigo defende-se que é possível uma relação profícua entre a Teologia e a Bioética, sobretudo, porque a primeira, desde sua perspectiva Pública, tem muito a oferecer à reflexão bioética. Todavia é preciso levar em conta que a forma como se realiza a reflexão teológica e, consequentemente, como se constrói o discurso bioético a partir dessa reflexão, precisa ser feita de tal modo que as proposições que daí surjam, possam ser mais ou menos razoáveis e, porque não, credíveis.

Seguindo a isso, é possível estabelecer essa relação, não só no plano teórico da reflexão teológica e bioética, mas em perspectivas muito práticas, uma vez que o intento tanto da Bioética, quanto da Teologia estabelece-se na necessidade de suscitar atitudes concretas que explicitem os valores que, via de regra, ambas defendem, como por exemplo e principalmente, o valor da vida. Assim sendo, a contribuição da Teologia Pública, em todo esse processo, acaba se tornando imprescindível e fundamental, em especial, em traçar uma estratégia que será necessária seguir para que a Bioética como um todo possa se enriquecer pela reflexão teológica.

Por fim, pode-se dizer que a reflexão bioética que ocorre no âmbito teológico precisa estabelecer intrinsicamente, ciente ou não, um diálogo com algumas características da Teologia Pública, tais como: abertura às ciências, diálogo com a sociedade, construção de argumentos com razoabilidade, consciência de que se atua em um cenário público e respeito à diversidade.

Concluindo, se faz mister enfatizar que o elemento mais exigente para uma Teologia que atua nas interfaces com a Bioética é posicionar-se bem neste ambiente secularizado, o que implica em lidar com a tensão entre "saber que tem algo a contribuir" e "saber que a sua contribuição é apenas uma entre outras". Ou seja, a Teologia - no diálogo com a Bioética - precisa aceitar que sua perspectiva não é a única possível, mas pode ser construtiva se situarse como um saber entre outros. Com esta postura a Teologia poderá marcar significativamente a Bioética e ser marcada por ela. 


\section{Referências bibliográficas}

AMOR PAN, J. R. Bernard Häring y la Bioética. Estudios Eclesiásticos, v. 74, n. 290, p. 513-550, jul./set. 1999.

FONTANA, V.; WESTPHAL, E. R. Teologia Pública e Bioética. In: ZWETSCH, R.; SINNER, R.; JACOBSEN, E. (Orgs.). Teologia Pública: em debate. São Leopoldo: Sinodal / EST, 2012 . p. 69-88. (Coleção Teologia Pública, 3).

GONÇALVES, A. Teologia Pública: entre a construção e a possibilidade prática de um discurso. Ciberteologia, v. 8, n. 38, p. 63-76, 2012.

GRACIA, D. Fundamentos de Bioética. Madrid: Eudema, 1989.

JÄHR, F. Bio-Ethic: eine umschau über die ethischen - Beziehungen des menschen zu tier und pflanze. Handweiser für Naturfreunde, v. 24, n. 1, p. 2-4, 1927.

KUZMA, C. A teologia no universo científico e a sua especificidade epistemológica. In: PASSOS, J. D.; SOARES, A. M. L. (Orgs.). Teologia Pública: reflexões sobre uma área de conhecimento e sua cidadania acadêmica. São Paulo: Paulinas, 2011. p. 231-247.

MARTY, M. E. Reinhold Niebuhr: Public Theology and the American Experience. Journal of Religion, v. 54, n. 4, p. 332-359, 1974.

MEDINA, G. V. Teologia Pública: una proposta para hablar teológicamente de temas sociales a la sociedad pluralista española. Revista de Fomento Social, v. 67, p. 635-665, 2012.

MUÑOZ, R. La religión em la esfera pública: tareas para la teología. Scripta Theologica, v. 43, p. 647-665, 2011.

POTTER, V. R. Bioethics: Bridge to the future. New Jersey: Prentice- Hall, 1971. POTTER, V. R. Bioética: Ponte para o futuro. São Paulo: Loyola, 2016.

SALAZAR, E. ¿Bioética: Ciencia o disciplina? Investigación en Enfermería: imágen y desarrollo, v. 5, n. 1-2, p. 65-77, 2003.

SANCHES, M. A. Brincando de Deus: bioética e as marcas sociais da genética. São Paulo: Ave Maria, 2007.

SANTOS, B. S. Por um novo senso comum: a ciência, o direito e a política na transição paradigmática. Porto: Afrontamento, 2006.

SINNER, R. V. Teologia Pública no Brasil. In: PASSOS, J. D.; SOARES, A. 
M. L. (Orgs.). Teologia Pública: reflexões sobre uma área de conhecimento e sua cidadania acadêmica. São Paulo: Paulinas, 2011. p. 264-276.

SINNER, R. V., Teologia Pública no Brasil: um primeiro balanço. Perspectiva Teológica, v. 44, n. 122, p. 11-28, jan./abr. 2012.

THIELMANN, R. Constructing a public Theology: the Church in a Pluralistic Culture. Louisville: Westminster / John Knox Press, 1991.

TRACY, D. A imaginação analógica: a teología cristã e a cultura do pluralismo. São Leopoldo: Unissinos, 2006. (Coleção Theologia Publica, 7).

TRACY, D. A Teologia na Esfera Pública: três tipos de discurso público. Perspectiva Teológica, v. 44, n. 122, p. 29-51, jan./abr. 2012.

TRACY, D. The analogical imagination: christian theology and cultura of pluralism. New York: Crossroad, 1981.

VICO PEINADO, J. Como hablar de "Bioética Teológica"? Moralia, v. 26, p. 439-473, 2003.

ZABATIERO, J. P. T. O público em “Teologia Pública”. Estudos Teológicos, v. 1, n. 1, p. 74-88, jan./jun. 2013.

Evandro Arlindo de Melo

Doutor em Teologia pela Pontifícia Universidade Católica do Paraná Docente do Departamento de Filosofia da Faculdade de Educação e Meio Ambiente de Clevelândia Clevelândia / PR - Brasil

E-mail: evandromelo@uol.com.br

Mário Antônio Sanches Doutor em Teologia pela Faculdade EST Docente Titular do Departamento de Teologia da Pontifícia Universidade Católica do Paraná Curitiba / PR - Brasil E-mail: m.sanches@pucpr.br

Recebido em: 11/07/19

Aprovado em: 01/06/20 